\title{
Genetic variability of Conopophaga lineata (Conopophagidae) (Wied-Neuwied, 1831) in Atlantic Forest fragments
}

\author{
Dantas, GPM. ${ }^{\mathrm{a}, \mathrm{c} *}$, Santos, FR. ${ }^{\mathrm{a}}$ and Marini, MA. ${ }^{\mathrm{b}}$ \\ aDepartamento de Biologia Geral, Instituto de Ciências Biológicas, Universidade Federal de Minas Gerais, \\ Avenida Presidente Antônio Carlos, 6627, CEP 31270-901, Belo Horizonte, MG, Brazil \\ bDepartamento de Zoologia, Instituto de Biologia, Universidade de Brasília, CEP 70910-900, Brasília, DF, Brazil \\ 'Departamento de Biologia/Genética, Instituto de Biologia, Universidade de São Paulo - USP, \\ Rua do Matão, 277, CEP 05508-090, São Paulo, SP, Brazil \\ *e-mail: giselebio@yahoo.com.br
}

Received May 28, 2007 - Accepted October 3, 2007 - Distributed December 1, 2007

(With 2 figures)

\begin{abstract}
Forest fragmentation affects bird populations in many ways, modifying the composition of communities and favouring open country species. The Atlantic Forest is considered one of the most important biomes in the world, due to its great biodiversity, accelerated rates of deforestation, and high endemism. Despite these characteristics, few studies have evaluated the effects of forest fragmentation in the genetic structure of Atlantic forest bird populations. So, this study aims to verify the effects of forest fragmentation in the genetic population structure of Conopophaga lineata, through RAPD markers. To achieve this goal, 89 C. lineata individuals were captured in nine Atlantic Forest fragments in Minas Gerais State. The RAPD data indicate that forest fragmentation has not affected the genetic variation of $C$. lineata populations (Mann-Whitney $\mathrm{U}=3.50 ; \mathrm{p}=0.11$ ). Great part of the genetic variability of this species is found within populations and it was not observed a correlation between genetic and geographic distance (Mantel test $\mathrm{t}=0.6250 ; \mathrm{p}=073$ ). UPGMA analyses did not show defined clades and all branches showed low statistical support. The low population differentiation observed in this species can be due to a high gene flow among populations or a recent fragmentation. Thus, the current diversity status of $C$. lineata populations indicates that this species is not significantly affected by fragmentation. However, more genetic studies are essential to improve conservation strategies of Brazilian Atlantic Forest birds.
\end{abstract}

Keywords: RAPD, passeriformes, birds.

\section{Variabilidade genética de Conopophaga lineata (Conopophagidae) em fragmentos florestais da Mata Atlântica}

\begin{abstract}
Resumo
A fragmentação florestal afeta populações de aves de muitas maneiras, modificando a composição das comunidades e favorecendo espécies de áreas abertas. A Mata Atlântica é considerada um dos biomas mais importantes do mundo, devido à sua grande biodiversidade, aos altos níveis endemismo e de desmatamento. Apesar destas características, poucos estudos avaliaram os efeitos da fragmentação florestal na estrutura genética de populações de aves desse ecossistema. Dessa forma, este estudo visa verificar os efeitos da fragmentação florestal na variabilidade genética de Conopophaga lineata, através de marcadores RAPD. Assim, foram capturados 89 indivíduos de $C$. lineata em nove fragmentos florestais da Mata Atlântica do Estado de Minas Gerais. Os dados de RAPD indicam que a fragmentação florestal não afetou a variabilidade genética de Conopophaga lineata (Mann-Whitney $U=3,50 ; p=0,11$ ). Grande parte da variabilidade dessa espécie se encontra dentro das populações e não foi observada correlação entre a distância geográfica e a distância genética (Teste de Mantel $\mathrm{t}=0,6250 ; \mathrm{p}=0.73$ ). A análise UPGMA não mostrou clados definidos e todos os ramos apresentaram baixo suporte estatístico. A reduzida diferenciação populacional observada nessa espécie pode ser devida a intenso fluxo gênico entre as populações ou à recente fragmentação na região. Assim, a situação atual das populações de $C$. lineata indica que essa espécie não é significativamente afetada pela fragmentação. Entretanto, futuros estudos genéticos são essenciais para melhorar as estratégias de conservação da avifauna da Mata Atlântica do Brasil.
\end{abstract}

Palavras-chave: RAPD, passeriformes, aves. 


\section{Introduction}

Severe changes in habitat's physical structure and conditions are caused by forest fragmentation, increasing the amount of borders and light incidence in core area, and, in addition, reducing humidity (Soulé, 1986). For a long time, it has been known that these effects result in loss of biodiversity by modifying the communities and reducing the number of species (Anjos and Boçon, 1999; Marini, 2001). When the matrix surrounding forest fragments becomes a barrier to organisms' dispersion, fragmentation can cause geographic isolation of populations (Haig and Avise, 1996; Frankham et al., 2002). This isolation reduces gene flow, which can lead to a loss of within-population genetic variability and an increase of between-populations genetic differentiation, due to the effects of inbreeding and genetic drift (Bates, 2000). Loss of genetic variability reduces populations' reproductive fitness and their adaptability to environmental changes, extreme weather conditions, presence of pollutants, diseases, pests, and parasites (Primack and Rodrigues, 2000; Margis et al., 2002).

Neotropical birds are believed to be more sedentary than temperate species, which makes them more susceptible to forest fragmentation effects (Bates, 2000). The knowledge on genetic factors, such as diversity and gene flow, is useful for a better understanding of the impacts of anthropogenic activities on bird populations (Haig and Avise, 1996). In the last decades, a great discussion has occurred about the effects of fragmentation in small and isolated populations (Bouzat, 2001). However, only few studies have demonstrated the effects of habitat fragmentation in the genetic variability of continental Passeriformes populations (Bouzat, 2001).

The Brazilian Atlantic Rain Forest originally presented an area of 1.1 million $\mathrm{km}^{2}$ and covered a large extension of the Brazilian coast. Nowadays, this biome is considered one of the world's most important conservation hotspots areas, due to its high levels of endemism and degradation, and it presents only $5 \%$ of its original area (Myers et al., 2000). Most of the remaining forested areas are located in regions of steep topography, where agriculture and cattle ranching are not economically viable.

Rufous Gnateater (Conopophaga lineata) (Conopophagidae: Passeriformes) (Weid, 1831) is a small understory insectivorous bird. This species is distributed in tropical and subtropical forests of South America (Sigrislt, 2005), from Paraguay and northeast Argentina to northeast Brazil (Sick, 1997). Despite its large distribution, few studies have been accomplished to understand its biology and ecology (Willis et al., 1983; Sick, 1997). Its wide distribution along the Atlantic Forest, its usually high abundance, and the facility to catch this animal in mist-nets, make this species an excellent model for studies concerned to the effects of forest fragmentation in the genetic variability of Neotropical species.

In this study, RAPD markers were used to evaluate the effects of forest fragmentation in the genetic variability of Conopophaga lineata populations. In particular, we (1) evaluated the intra and inter population genetic variability of $C$. lineata, (2) estimated the number of migrants among the populations, (3) verified if the genetic variability is correlated to fragment size, and (4) verified if there is correlation between geographic and genetic distance.

\section{Material and Methods}

\subsection{Study area}

The present study was carried out from August 2000 to November 2001. Rufous Gnateaters were captured using mist nets at five locations in Minas Gerais State, Brazil (Figure 1). In each location, two fragments were sampled (totaling 10 fragments): a large one ( $>1,000 \mathrm{ha}$ ) and a small one (10-30 ha) (Table 1), which were, at least, $1 \mathrm{~km}$ apart from each other. However, in the large fragment of Caratinga, no individual was captured (see Table 1). Fragments were surrounded by a matrix of monocultures or pasturelands. It is believed that 100 meters of open area would be enough to create a barrier to the dispersal of several understory forest birds (Kattan et al., 1994). Since all of the localities sampled in this work were at least $1 \mathrm{~km}$ apart from the nearest fragment, all of them were considered as an isolated population. Captured birds received a metal band provided by CEMAVE/IBAMA, Brazil. The capture effort was the same in all localities.

\subsection{Sample and extraction of DNA}

Blood samples were collected $(\sim 0.1 \mathrm{~mL})$ from the tarsus vein, and kept in $70 \%$ ethanol at $4{ }^{\circ} \mathrm{C}$ for posterior laboratory analysis. Genomic DNA was isolated from blood samples through a standard phenol/chloroform technique, precipitated with ethanol, and ressuspended in TE buffer (Tris-EDTA) (Sambrook et al., 2001).

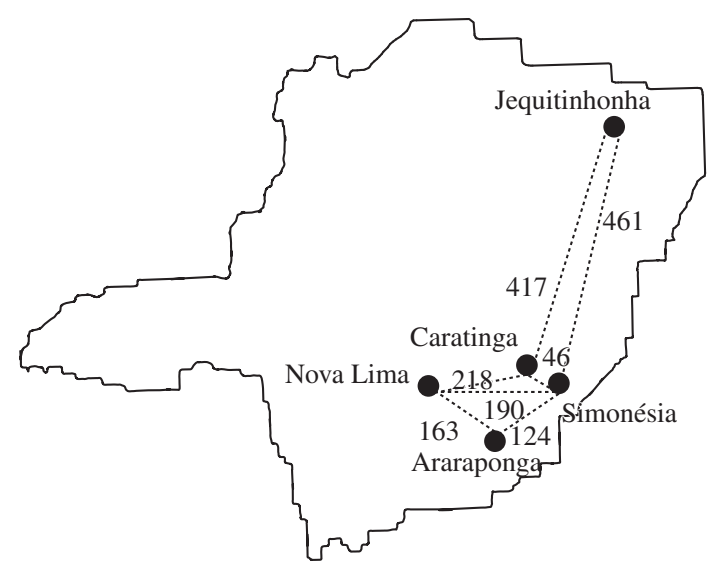

Figure 1. Localities where $C$. lineata was sampled in the Atlantic Forest of the State of Minas Gerais: 1) Simonésia; 2) Jequitinhonha; 3) Araponga; 4) Nova Lima; and 5) Caratinga. Distances $(\mathrm{km})$ between areas are indicated. 
Table 1. C. lineata populations sampled at Minas Gerais State, Brazil (N - Samples number, pop - population name)

\begin{tabular}{lllcrr}
\hline Region & \multicolumn{1}{c}{ Fragments } & Localities & Fragment size & pop & N \\
\hline \multirow{2}{*}{ Southeast } & João Ribas & Araponga & 20 ha & SUD 1 & 18 \\
& Brigadeiro & Araponga & 13,210 ha & SUD 2 & 8 \\
East & Mata dos Padres & Caratinga & 50 ha & LES 1 & 11 \\
& Reserva de & Caratinga & 1,200 ha & - & 0 \\
& Caratinga & & & LES 2 & 8 \\
& Mata do Lula & Simonésia & 30 ha & LES 3 & 6 \\
& Sossego & Simonésia & 1,000 ha & CEN 1 & 6 \\
Central & Jambreiro & Nova Lima & 1,000 ha & CEN 2 & 10 \\
& Mata dos Primos & Nova Lima & 22 ha & CEN 3 & 12 \\
North & Mata da Piedade & Nova Lima & 25 ha & NOR 1 & 10 \\
\hline Total & Mata Escura & Jequitinhonha & 5,000 ha & & 89 \\
\hline
\end{tabular}

ha $=$ hectare.

\subsection{RAPD-PCR Procedures}

Amplifications were carried out in $12.5 \mu \mathrm{L}$ final volume containing: 1x Taq polymerase buffer $(10 \mathrm{mM}$ Tris- $\mathrm{HCl} \mathrm{pH} 8.3,50 \mathrm{mM} \mathrm{KCl}), 2.5 \mathrm{mM} \mathrm{MgCl}_{2}, 200 \mu \mathrm{M}$ dNTPs, $1 \mu \mathrm{M}$ primer, $1 \mathrm{U}$ of Taq polymerase, and $20 \mathrm{ng}$ of genomic DNA. PCR reactions were performed on a PTC-100 ${ }^{\mathrm{TM}}$ (M.J. Research, Inc.) thermocycler, using the following conditions: an initial denaturation step of $95{ }^{\circ} \mathrm{C}$ for 1 minute, followed by 35 cycles of $94{ }^{\circ} \mathrm{C}$ for 20 seconds, $36{ }^{\circ} \mathrm{C}$ for 1 minute, $72{ }^{\circ} \mathrm{C}$ for 1 minute, and a final extension of $72{ }^{\circ} \mathrm{C}$ for 7 minutes. Negative controls, in which DNA was omitted, were included in each run in order to verify the absence of contamination. Amplification products were analyzed by electrophoresis in $6.0 \%$ acrylamide gels, made with $1 \times$ TBE buffer. The bands were visualized by silver staining (Santos et al., 1996). Fragment sizes were estimated using a 100-bp ladder (Life Technologies), and the primers that consistently produced sharp and reproducible RAPD products (bands), over two independent runs, were chosen for this study. In each gel, PCR products for profiles that were known from previous gels were used as positive controls. This procedure allowed comparing the gels and monitoring the reproducibility of the technique throughout the experiment. The few non-reproducible bands, i.e. those bands that fail to reproduce after the two independent runs of the pilot study, and the bands that appeared in the positive controls, were not considered for the analysis.

\subsection{Statistical analyses}

Each band was considered as an independent locus, and those that co-migrated were assumed to be homologous. For the analysis, a matrix of RAPD phenotypes was assembled, in which RAPD bands were scored as present (1) or absent (0). Weak bands were considered artifacts and were not included in the band scores for statistical analyses.

A pairwise Euclidean distance matrix was generated using the program AMOVA-PREP (obtained from
MP. Miller, http://herb.bio.nau.edu/ miller/amovaprp. $\mathrm{htm}$ ), which was used as the input file for the program WinAMOVA 1.55 (obtained from L. Excoffier, http:// lgb.unige.ch/software/win/amova). The latter program performs a classical analysis of variance (Analysis of Molecular Variance - AMOVA) based on the distances, partitioning the variation into within and between population components (Excoffier et al., 1992). Although originally designed for haploid data (mitochondrial DNA), the AMOVA has been successfully applied to the analysis of RAPD phenotypes (Huff et al., 1993; Palacios and González-Candelas, 1997; Mockford et al., 1999). A nonparametric permutation procedure tests the significance of differences between populations by simulating methods in which individuals are randomly reallocated into populations, and the null distribution of each variance component is estimated from 1,000 independent runs of this process (Excoffier et al., 1992). The WinAMOVA produces a matrix of pairwise $\Phi_{\text {ST }}$ values (an $\mathrm{F}_{\mathrm{ST}}$ analogue), which was used to estimate the effective number of migrants $(\mathrm{Nm})$ between populations $\left[\mathrm{Nm}=0.25\left(1 / \mathrm{F}_{\mathrm{ST}}-1\right)\right.$; Wright, 1951]. Nei genetic distance was calculated through TFPGA (Tools for Population Genetic Analysis, www.marksgeneticsoftware.net/tfga.htm), to construct an UPGMA tree with bootstrap confidence tests in Paup 3.0 (Swofford, 2002).

Genetic variance of each population was obtained through the square sum given by WinAMOVA 1.55 program divided by the degrees of freedom of each population, which were obtained by subtracting 1 to the number of individuals sampled in the populations $(N-1)$. To test if fragment size affects the genetic variability of the populations, we used Mann-Whitney Test and compared the genetic variance of the populations from larger and smaller fragments in each location.

We estimated the geographic distances between populations by measuring the linear distance between pairwise fragments. Then, we used Spearman correlation test to compare $\mathrm{Nm}$ (estimated number of migrants) and 
geographic distances, and the Mantel test implemented in Arlequin (Excoffier, 2006) to compare Nei genetic distances and geographical distances.

\section{Results}

We used 10 individuals of $C$. lineata from different localities in the Minas Gerais State, in order to test 30 RAPD primers. Only five primers generated clear and reproducible bands: primer 04 (CCCGCGGCCTATGAG), primer 13 (CCAGGGTGAGCGGCT), primer 27 (CAGGCCCCGAACAAT), primer 29 (GCACGCATGGTTTGC), and primer 30 (CCCCGAGAAGCCTGA).

We scored 114 markers (bands) in 89 C. lineata individuals - 16 monomorphic and 98 polymorphic - which corresponded to $85.96 \%$ of polymorphism. All bands were included in the analyses and they showed a size between 250 and 1,600 base pairs (bp). Each individual showed a distinct band pattern considering the results of all primers together, as well as considering the data obtained with each primer separately. No exclusive bands were found for any population.

A great part of the genetic variation $(87.75 \%)$ was found within the $C$. lineata populations (Table 2) and the genetic differentiation among regions of the Minas Gerais State was small (1.48\%). The calculated fixation index was moderate but non-significant $\left(\Phi_{\mathrm{ST}}=0.122\right.$, $\mathrm{p}=0.18)$.

It was not found a significant difference in the genetic variance of populations when comparing small and large forests fragments (Mann Whitney test; $U=3.50$; $\mathrm{p}=0.11$ ) (Figure 2). The Spearman correlation between the number of migrants and the geographical distance was low but significant (Spearman Rank Correlation, $\mathrm{r}=-0.23 ; \mathrm{p}<0.01)$. However, the Mantel test used to evaluate the correlation between genetic and geographic distances has not shown any significant result (Mantel $t$-test $=0.6250 ; \mathrm{p}=0.73$ ). The UPGMA analysis did not show association between geographical and genetic distribution (data not shown).

\section{Discussion}

Some researches have demonstrated that RAPD results were similar to the outcomes of other genetic markers such as allozymes, RFLP, and mitochondrial DNA (Crochet, 2000; Kjolner et al., 2004). In this study, this marker showed reproducibly, which allowed important inferences on the genetic structure of one Passeriformes species from the Atlantic Forest. This is the first study with genetic markers applied to analyze the effects of fragmentation in neotropical species populations. Despite the fact that tropical ecosystems show the greater species diversity in the world, little is known about the genetic structure of birds' populations from these ecosystems (Bates, 2000).

The genetic variation within and between populations is fundamental in keeping the evolutionary process (Zink et al., 1987; McCauley, 1991). The reduction of the intra-population genetic variability can be the result of stochastic events associated with small population size and inbreeding (Souza et al., 2002). It is expected that fragmentation reduces population size and, consequently, increases inbreeding effects.

However, our data indicate that a great part of the total genetic variability of $C$. lineata populations is found within the populations $(87.75 \%)$ and a smaller amount of genetic divergence can be found between populations $(10.77 \%)$ and also between regions $(1.48 \%)$. The calculated $\Phi_{\mathrm{ST}}$ for $C$. lineata was 0.122 , though not significant. The lack of population structure was corroborated by the UPGMA analysis, which showed that there is no relationship between genetic differentiation and the geographic distances between $C$. lineata populations. Besides, the low genetic differentiation observed in $C$. lineata can be the result of a high gene flow among populations or due to a recent fragmentation. Altogether, these results indicate that $C$. lineata populations in Minas Gerais State represent a single panmitic population.

Several birds show low population structure, because they are vagile organisms (Crochet, 2000; Caizergues et al., 2003). The migration is a potent force against ge-

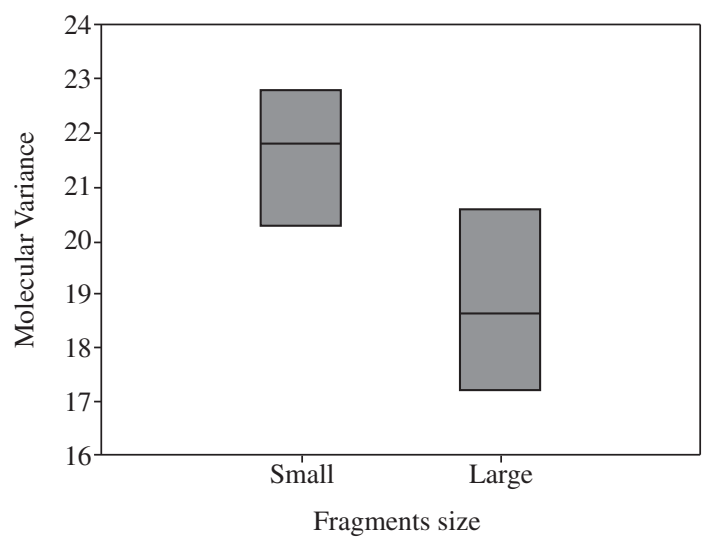

Figure 2. Boxplot of genetic variance of $C$. lineata populations in small and large forest fragments.

Table 2. Molecular Variance Analysis (AMOVA) of RAPD analysis of $C$. lineata populations in Atlantic Forest, MG.

\begin{tabular}{lcccc}
\hline \multicolumn{1}{c}{ Components variation } & d.f. & variance & total \% & P \\
\hline Among regions & 3 & 0.354 & 1.48 & 0.180 \\
Among populations within regions & 6 & 2.587 & 10.77 & 0.001 \\
Within Populations & 84 & 21.074 & 87.75 & 0.001 \\
\hline
\end{tabular}

$\Phi_{\mathrm{ST}}=0.122 ; \Phi_{\mathrm{SC}}=0.109 ; \Phi_{\mathrm{CT}}=0.015 ;$ d.f. = Freedom degree; e P = exact probability from test. 
netic divergence among populations (Hartl and Clark, 1989). However, organism dispersion is directly affected by distance and by the matrix that involves the fragments (Frankham et al., 2002). Bates $(2000,2002)$ observed that fragmentation effects in the genetic diversity of Amazonian understory Passeriformes seem to be related with the capacity of locomotion of the species.

We found a low and negative correlation between the number of migrants and the geographical distance between the populations $(r=-0.23)$, which can indicate that individuals can be dispersing across the matrix among forest fragments (Table 3). This conclusion is in agreement with Ribon (1998) since he observed that $C$. lineata and Thamnophilus caerulescens were the only understory species that remained in all the Atlantic Forest fragments. This author also observed that these species were also found in small fragments, so he suggested that these species should frequently move through open areas.

Other explanation to the lack of population structure observed in Minas Gerais State could be related to the time of isolation of these populations. There is still no consensus about the time needed to habitat fragmentation to cause changes in the genetic structure of populations. Some argue that recent fragmentation, i.e. less than 200 years, may not cause an effect in the genetic structure of the populations (Haig et al., 1994; Haig et al., 1996). Other authors believe that the decline of genetic variability after the reduction of a population can be observed after 50-100 generations (Tarr and Fleischer, 1999). However, the fragmentation process is occurring since the year 1500, when Brazil was discovered, but the intense fragmentation in the studied region is recent ( $<100$ years). As so, it is possible that the isolation time was not sufficient to cause the differentiation of the populations.

The size of the fragments has not affected the genetic variability of $C$. lineata $(\mathrm{U}=3.50 ; \mathrm{p}=0.11)$ (Figure 2$)$. We did not find significant difference between the genetic variance of populations comparing small and large fragments. Conopophaga lineata is a generalist species, capable of using great diversity of food resources. This species has survived in disturbed areas, such as second- ary forests and forest borders (Sick, 1997). We observed a higher capture of individuals in small fragments than in the larger ones, and this fact can indicate that populations in small fragments can be at least as numerous as the populations in the larger fragments. However, rare species can show other patterns and the forest fragmentation can be affecting these species in more severe ways. Lunardi (2004) studied Conopophaga melanops, that is restrict to forest habitat, in one transect of $250 \mathrm{~km}$ along the Atlantic Forest at São Paulo State. He observed that C. melanops is more sensitive to fragmentation, showing statistically significant differences along the transect. Species composition in small fragments is usually a sub sample of the assemblage in the larger fragments, and local extinction post fragmentation is not a random process (Kattan et al., 1994). The extinction of several species in small fragments can be related with the reduction of food resources and the availability of reproductive and foraging areas, with loss of genetic variability, and the capacity to adapt to extreme environmental conditions.

The results of this study increase the conservation alternatives for this species. So far, it is of general agreement that forest fragmentation is affecting species in different ways: generalist and specialist species. Generalist species can be able to adapt to changes in the environmental conditions, keeping their populations with viable numbers, while specialist species can be extremely sensitive to forest fragmentation. Thus, future studies with neotropical birds with different life styles from the Atlantic Forest are extremely important to a better understanding of the effects of forest fragmentation in these animals.

Acknowledgments - This study was developed in the graduate program of 'Ecologia, Conservação e Manejo da Vida Silvestre' - UFMG, with support from USFWS, CNPq, and CAPES. Fieldwork was funded by a grant from CNPq to MÂM and lab work was funded by the Brazilian Long Term Ecological Research grant from CNPq to FRS. We would like to thank the owners and administrators for their permission to collect in their properties, and IBAMA for collecting and banding permits. We are especially grateful to L. Lopes, A. Fernandes, and F. Sebaio for help in the field and D. Lacerda and R. Redondo for technical help in the laboratory. MJF. Silva, C. Miyaki, C. Jacobi and B.

Table 3. Nei genetic distance (hemimatrix inferior) and number of migrants (Nm) (hemimatrix superior) of pairwised $C$. lineata populations.

\begin{tabular}{cccccccccc}
\hline Population & SUD 1 & SUD 2 & LES 1 & LES 2 & LES 3 & CEN 1 & CEN 2 & CEN 3 & NOR 1 \\
\hline SUD 1 & & 2.6335 & 7.8668 & 1.2809 & 2.1631 & 6.0951 & 2.6911 & 2.5909 & 1.469 \\
SUD 2 & 0.0779 & & 2.6335 & 1.5855 & 5.4189 & 2.7839 & 1.7388 & 1.3947 & 0.8547 \\
LES 1 & 0.0502 & 0.1081 & & 2.1515 & 2.4209 & 2.8946 & 4.9367 & 3.7887 & 1.203 \\
LES 2 & 0.1236 & 0.1151 & 0.1168 & & 0.9176 & 0.9226 & 1.1089 & 1.5950 & 1.1109 \\
LES 3 & 0.1025 & 0.1013 & 0.1261 & 0.1800 & & 16.75 & 1.3639 & 0.9653 & 1.1925 \\
CEN 1 & 0.0703 & 0.1034 & 0.1072 & 0.1715 & 0.0555 & & 2.6502 & 1.8076 & 3.7182 \\
CEN 2 & 0.7011 & 0.1259 & 0.0787 & 0.1574 & 0.1457 & 0.0892 & & 2.5653 & 1.4222 \\
CEN 3 & 0.0782 & 0.1250 & 0.0722 & 0.1265 & 0.1768 & 0.1163 & 0.0750 & & 0.9707 \\
NOR 1 & 0.1209 & 0.1780 & 0.1544 & 0.2146 & 0.1028 & 0.0794 & 0.1335 & 0.1696 & \\
\hline
\end{tabular}


Lovato provided criticisms and reviews of previous drafts of the manuscript.

\section{References}

ANJOS, L. and BOÇON, R., 1999. Bird communities in natural forest patches in southern Brazil. Wilson Bull., vol. 111, no. 3, p. $397-414$.

BATES, JM., 2000. Allozymic genetic structure e natural habitat fragmentation: data for five species of Amazonian forest birds. Condor, vol.102, no. 4, p.770-783.

BATES, JM., 2002. The genetics effects of forest fragmentation on five species of Amazonian birds. J. Avian Biol., vol. 33, no. 3, p. 276-294.

BOUZAT, JL., 2001. The population genetic structure of Greater Rhea (Rhea americana) in an agricultural landscape. Biol. Conserv., vol. 99, no. 3, p. 277-284.

CAIZERGUES, A., RATTI, O., HELle, P., ROTELli, L., ELLISON, L., and RASPLUS, J-Y., 2003. Population genetic structure of male black grouse (Tetrao tetrix) in fragmented versus continuous landscape. Mol. Ecol., vol. 12, no. 9, p. 2297-2305.

CROCHET, PA., 2000. Genetic structure of avian populationsallozymes revisited. Mol. Ecol., vol. 9, no. 10, p. 1463-1469.

EXCOFFIER, L., 2006. An Integrated Software Package for Population Genetics. (http://cmpg.unibe.ch/software/ arlequin3).

EXCOFFIER, L., SMOUSE, PE. and JOSEPH, MQ., 1992. Analysis of molecular variance inferred from metric distances among DNA haplotypes: Application to human mitochondrial DNA restriction data. Genetics, vol. 131, no. 2, p. 479-491.

FRANKHAM, R., BALLOU, JD. and BRISCOE, DA., 2002. Introduction to Conservation Genetics. United Kingdom, Cambrigde, 617p.

HAIG, SM. and AVISE, JC., 1996. Avian Conservation Genetics. In AVISE, JC. (ed.) Conservation Genetics: Case histories from nature. New York, Chapman \& Hall, p. 160-189.

HAIG, SM., BOWMAN, R. and MULLINS, TD., 1996. Population structure of Red-cockaded Woodpeckers in south Florida: RAPDs revisited. Mol. Ecol., vol. 5, no. 5, p. 725-734.

HAIG, SM., RHYMER, JM. and HECKEL, DG., 1994. Population differentiation in randomly amplified polymorphic DNA of Red-cockaded Woodpeckers Picoides borealis. Mol. Ecol., vol. 3, no. 3, p. 581-595.

HARTL, DL. and CLARK, AG., 1989. Principles of population genetics. Massachusetts, USA, Sinauer Associates, 488p.

HUFF, DR., PEAKALL, R. and SMOUSE, PE., 1993. RAPD variation within and among natural populations of outcrossing buffalograss [Buchloë dactyloides (Nutt.) Engelm.]. Theor. Appl. Genet., vol. 86, no. 8, p. 927-934.

KATTAN, GH., ALVAREZ-LOPEZ, H. and GIRALDO, M., 1994. Forest fragmentation and bird extinctions: San Antonio eighty years later. Conserv. Biol., vol. 8, no. 1, p. 138-146.

KJOLNER, S., SASTAD, SM., and TABERLET, P., 2004. Amplified fragment length polymorphism versus random amplified polymorphic DNA markers: clonal diversity in Saxifraga cernua. Mol. Ecol., vol. 13, no. 1, p. 81-86.
LUNARDI, VO., 2004. Análise genética molecular (RAPD) de Conopophaga melanops, Vieillot 1818 (Aves, Conopophagidae), em escala fina de Mata Atlântica e sua implicação para a conservação da espécie. 58p. (Dissertação de Mestrado) Universidade Federal de São Carlos, São Carlos, SP.

MARGIS, R., FELIX, D., CALDAS, JF., SALGUEIRO, F., ARAUJO, DSD., BREYNE, P., VAN MONTAGU, M., OLIVEIRA, D. and MARGIS-PINHEIRO, M., 2002. Genetic differentiation among three neighboring Brazil-cherry (Eugenia uniflora L.) populations within the Brazilian Atlantic rain forest. Biodivers. Conserv., vol. 11, no. 1, p. 149-163.

MARINI, MÂ., 2001. Effects of forest fragmentation on birds of the cerrado region, Brazil. Bird Conserv. Int., vol. 11, no. 1, p. 13-25.

MCCAULEY, DE., 1991. Genetics consequences of local population extinction and recolonization. Trends Ecol. Evol., vol. 6 , no. 1, p. $5-8$.

MOCKFORD, SW., SNYDER, M. and HERMAN, TB., 1999. A preliminary examination of genetic variation in a peripheral population of Blanding's turtle, Emydoidea blandingii. Mol. Ecol., vol. 8, no. 2, p. 323-327.

MYERS, N., MITTERMEIER, RA., MITTERMEIER, CG., FONSECA, GAB. and KENT, J., 2000. Biodiversity hotpots for conservation priorities. Nature, vol. 403, p. 853-858.

PALACIOS, C. and GONZÁLEZ-CANDELAS, F., 1997. Analysis of population genetic structure and variability using RAPD markers in the endemic and endangered Limonium dufourii (Plumbaginaceae) Mol. Ecol., vol. 6, no. 12, p. 1107-1121.

PRIMACK, RB. and RODRIGUES, E., 2001. Biologia da Conservação. Paraná, Brasil, Midiograf, 327p.

RIBON, R., 1998. Fatores que influenciam a distribuição da avifauna em fragmentos de Mata Atlântica nas montanhas de Minas Gerais. 110p. (Dissertação de Mestrado), Universidade Federal de Minas Gerais, Belo Horizonte, MG.

SAMBROOK, KJ., RUSSELL, DW. and SAMBROOK, J., 2001. Molecular cloning: a laboratory manual. New York, EUA, CSHL Press.

SANTOS, FR., BIANCHI, NO. and PENA, SD., 1996. Worldwide distribution of human Y-chromosome haplotypes. Genome Res., vol. 6, no. 7, p. 601-611.

SICK, H., 1997. Ornitologia Brasileira. Rio de Janeiro, Nova Fronteira, 912p.

SIGRISLT, T., 2005. Aves do Brasil: uma visão artística. São Paulo, Brasil, Editora Avis Brasilis, 627p.

SOULÉ, ME., 1986. Conservation biology: The Science of scarcity and diversity. Sunderland, Massachussets, EUA, Sinauer Associates, 584p.

SOUZA, FL., CUNHA, AF., OLIVEIRA, MA., PEREIRA, GAG., PINHEIRO, HP. AND REIS, SF., 2002. Partitioning of molecular variation at local spatial scales in the vulnerable tropical freshwater turtle, Hydromeduza maximiliani (Testudines, Chelidae): implications for conservation of aquatic organisms in natural hierarchical systems. Biol. Conserv., vol. 104 , no. 1 , p. 119-126.

SWOFFORD, DL., 2002. PAUP*. Phylogenetic analysis using parsimony (*and other methods). Version 4. Sunderland, Massachussets, EUA, Sinauer Associates. 128p. 
TARR, CL. and FLEISCHER, RC., 1999. Population boundaries and genetic diversity in endangered Mariana Crow (Corvus kubaryi). Mol. Ecol., vol. 8, no. 6, p. 941-949.

WILLIS, EO., ONIKI, Y. and SILVA, WR., 1983. On the behaviour of Rufous Gnateaters (Conopophaga lineata, Formicariidae). Naturalia, vol. 8, p. 67-93.
WRIGHT, S., 1951. The genetical structure of populations. Ann. Eugenet., vol. 15, p. 323-354.

ZINK, RM., LOTT, DF. and ANDERSON, DW., 1987. Genetic variation, population structure and evolution of California Quail. Condor, vol. 89, no. 2, p. 395-405. 
